\title{
The political ecology of late South American pastoralism: an Andean perspective A.D. 1,000-1,615
}

\author{
Jennifer Grant ${ }^{\mathrm{a} 1}$ \\ Kevin Lane ${ }^{\mathrm{b}}$

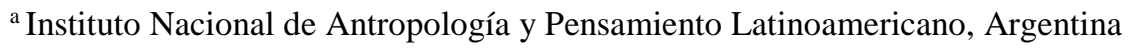 \\ ${ }^{\mathrm{b}}$ Universidad de Buenos Aires, Argentina
}

\begin{abstract}
Prehispanic South American pastoralism has a long and rich, though often understudied, trajectory. In this paper, we analyze the transition from a generalized to a specialized pastoralism at two geographical locations in the Andes: Antofagasta de la Sierra, Southern Argentina Puna, and the Ancash Highlands, Peruvian Northcentral Puna. Although at opposite ends of the Andes this herding specialization commences during the same moment in time, A.D. 600-1,000, suggesting that a similar process was at work in both areas. Moreover, this was a process that was irrevocably tied to the coeval development of specialized highland agriculture. From a perspective of political ecology and structuration theory we emphasis the time-depth and importance that Andean pastoralism had in shaping highland landscapes. Taking into consideration risk-management theory, ecology and environment as crucial factors in the development of a specialized pastoralism we nevertheless emphasis the importance of the underlying human decisions that drove this process. Based broadly within the field of political ecology we therefore emphasize how human agency and structure impacted on these landscapes, society and animal husbandry. Our article covers such aspects as the human and animal use of resource areas, settlement location, herding patterns, selective breeding, and human-induced alterations to pasturage.
\end{abstract}

Keywords: Andes, pastoralism, political ecology, Southern Andes, Central Andes

\section{Résumé}

Le pastoralisme préhispanique sud-américain a une trajectoire longue et riche, mais souvent peu étudiée. Dans cet article, nous analysons le passage d'un pastoralisme généralisé à un pastoralisme spécialisé dans deux régions géographiques des Andes: Antofagasta de la Sierra, Puna du sud de l'Argentine et Hautes-terres d'Ancash, Puna du centre-nord du Pérou. Bien que, aux extrémités opposées des Andes, cette spécialisation de l'élevage commence au même moment, soit 600-1,000 après J.-C., ce qui suggère qu'un processus similaire était à l'œuvre dans les deux zones. En outre, il s’agissait d'un processus irrévocablement lié au développement de l'agriculture spécialisée dans les montagnes. Du point de vue de l'écologie politique et de la théorie de la structuration, nous insistons sur l'importance temporelle et l'importance que le pastoralisme andin a eu dans la formation des paysages de montagne. Compte tenu de la théorie de la gestion des risques, de l'écologie et de l'environnement en tant que facteurs cruciaux dans le développement d'un pastoralisme spécialisé, nous insistons néanmoins sur l'importance des décisions humaines sous-jacentes à la base de ce processus. Fondamentalement, dans le domaine de l'écologie politique, nous insistons donc sur la manière dont l'action et la structure humaines ont eu un impact sur ces paysages, la société et l'élevage. Notre article couvre des aspects

\footnotetext{
${ }^{1}$ Dr. Jennifer Grant, CONICET Postdoctoral Fellow, Instituto Nacional de Antropología y Pensamiento Latinoamericano, Argentina Email: jennygrantlett "at" gmail.com and Dr. Kevin Lane, CONICET Researcher, Instituto de Arqueología, Universidad de Buenos Aires, Argentina, Argentina. Email: kevin.lane "at" cantab.net. The write-up for this article was supported by the Gerda Henkel Foundation. The Argentinean research was financed by grants from CONICET (PIP 112), UBACyT (F-122), ANPCyT (PICT-26023) and a Doctoral Fellowship from CONICET. Jennifer Grant is indebted to Daniel Olivera for the development of these investigation themes. The Peruvian research was made possible by grants from the British Academy (R103625/2007 and SG50348/2008), and post-doctoral fellowships for Kevin Lane by the Leverhulme Foundation (2007-2009), Sainsbury's Research Unit (2009) and the Alexander von Humboldt Foundation (2011-2012). Final thanks go to Prof. Casey Walsh, Prof. Simon Batterbury, and the anonymous reviewers. As always, all errors remain the authors.
} 
tels que l'utilisation humaine et animale des zones de ressources, la localisation de la colonisation, les modes d'élevage, la reproduction sélective et les modifications anthropiques des pâturages.

Mots-clés: Andes, pastoralisme, écologie politique, Andes du Sud, Andes centrales

\section{Resumen}

La ecología politica del pastoralismo Sudamericano tardío: una persepectiva Andina 1,000-1,615 d.C. El pastoralismo prehispánico en América del Sur tiene una larga y rica trayectoria, aunque a menudo poco estudiada. En este trabajo, analizamos la transición desde un pastoreo generalizado hacia uno especializado en dos ubicaciones geográficas de los Andes: Antofagasta de la Sierra, en la Puna sur Argentina, y las tierras altas de Ancash, en la Puna Nor-central peruana. Si bien en los extremos opuestos de los Andes, esta especialización pastoril comienza durante el mismo momento en el tiempo, 600-1,000 D.c., lo cual sugiere que un proceso similar estaba actuando en ambas áreas. Más aún, este proceso estuvo unido irrevocablemente al desarrollo coetáneo de una agricultura especializada de altura. Desde la perspectiva brindada por la ecología política y la teoría de la estructuración, enfatizamos en la profundidad temporal y la importancia que el pastoreo andino tuvo en configurar los paisajes de altura. Al tomar en consideración la teoría del manejo de riesgo, la ecología y el ambiente como factores cruciales en el desarrollo de un pastoreo especializado enfatizamos, no obstante, la importancia de las decisiones humanas subyacentes que guiaron estos procesos. Basados ampliamente dentro del campo de la ecología política, enfatizamos cómo la agencia humana y la estructura impactaron en estos paisajes, sociedades y manejo de animales. Nuestro artículo cubre aspectos tales como el uso humano y animal de áreas de recursos, ubicación de asentamientos, estrategias de pastoreo, crianza selectiva y alteraciones inducidas por los humanos sobre las pasturas.

Palabras clave: Andes, pastoreo, ecología política, Andes Meridionales, Andes Centrales

\section{Introduction}

Political ecology is not a strictly delimited theoretical framework but should be viewed more as a tool for orientation in terms of research and analysis. (Rasmussen 2015: 6)

The last thirty years has exposed the inaccuracy of Khazanov's cursory assessment that, "Highland or alpine pastoralism (transhumance) in ...the Andes... never was anything else, than a specialized branch of an agricultural economy..." (1984: xxxvii-xxxviii). Rather, research has emphasized the deep-time, varied and complex nature of this economic adaptation to the Andean highlands (Browman 2008; Capriles 2011; Kuznar 1990; Mengoni 2008; Mengoni and Yacobaccio 2006, Moore 2016). Prehispanic pastoralism in the Andes involved camelid herding. The two domestic camelids, the llama and alpaca, are derived respectively from the wild guanaco and vicuña. While the llama (Lama glama) was present in Northwest Argentina (Mengoni and Yacobaccio 2006; Olivera 1997), the other domesticated camelid species, the alpaca (Vicugna pacos) was virtually inexistent in the Argentine Puna, given that the area is too dry for the environmental requirements of this animal (Vilá 2000). In contrast, both the llama and alpaca are, or were, present in the Central Andes (Franklin 1982).

Given the inherent complexity in Andean herding, this article examines the emergence of specialized camelid pastoralism during the later Prehispanic Period (AD 1,000-1,480). In so doing, we detail this specialized pastoralism at opposite ends of the Andean chain, at Antofagasta de la Sierra in the Southern Argentina Puna, and in the Ancash Highlands part of the Peruvian North-central Puna (Figure 1). Specialized herding commenced in both areas at roughly the same time (c.A.D. 600-1,000), forcing us to consider the underlining factors that conditioned this increased specialization.

We maintain that this specialized pastoralism is linked to coeval developments within highland agriculture that encouraged the growth of almost exclusive, though interdependent, herders and farmers within a broader agro-pastoralist social, cultural and economic framework. Nevertheless, this development did not necessarily imply herder subservience to agriculturalists; rather, place and context mattered in the social makeup of these late Prehispanic societies. Indeed, the archaeological and ethnohistoric evidence provides 
sufficient examples to underscore the importance of herders in the social, cultural, economic and cosmological makeup of late Andean cultural adaptations to the highlands (Dedenbach-Salazar Sáenz 1990; Mengoni and Yacobaccio 2006; Wheeler, Russel and Redden 1995). This in effect reverses the dominant 'farmers first' agrocentric paradigm so present in many Andean studies (Lane 2006a), models which are often brought in uncritically from Old World examples. Collaterally, we also re-assess the fundamental importance of pastoralism in the formation of late Prehispanic highland political structures, and indeed throughout Andean cultural development opting for a more nuanced understanding of the importance of pastoralism in the formation of highland polities.

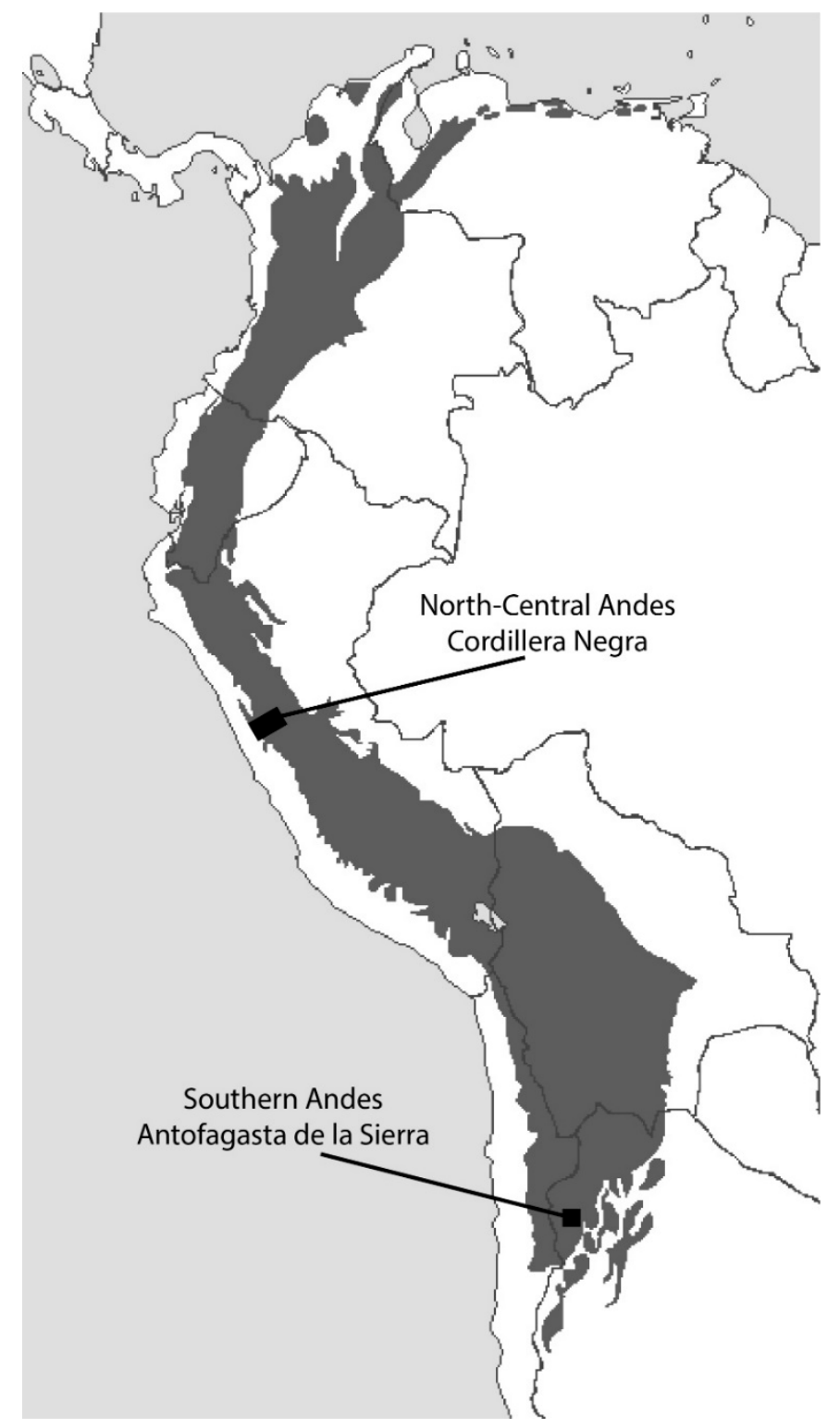

Figure 1: Map of the Andes, South America, showing both study areas. Source: Creative Commons, adapted by authors 
The wider issue of Andean pastoralism's supposed historic marginality, combined with our research into the social and economic inequities inherent in the human use and access of space and environmental resources during this period, places our study within a political ecology framework (Greenberg and Park 1994; Robbins 2004). We understand political ecology as a broad field of study that critically analyzes the ecological cost of human power relations and concomitant action on the environment. Rather than tending to highlight the negative costs on the ecology - a core concern of modern political ecologists (Robbins 2004: 14) - our standpoint also examines the possible, positive by-products of human action. By power we understand the asymmetrical relationships and access to resources between different human groups in a given place (Earle 1997).

By human action, as seen in these case-studies, we seek to emphasize the obvious, and the more ephemeral. In both, Antofagasta de la Sierra and the North-central Andes we study the interplay between people, landscape and technology assessing what these anthropogenic changes implied for land-use and the environment. In these study areas, we emphasis the importance that pastoralism had in conditioning societal development regionally. We define 'the environment', as the natural space in which these actions and other biophysical processes occur including the local geography, geology and ecology (Anschuetz, Wilshusen and Scheick 2001; Reboratti 2000). We understand the environment as dynamic and open, not static and closed (Butzer 1982). We reserve the term 'landscape' to define the multi-layered social, economic and cosmological ordering that humans ascribe to places (from Sauer 1925; see also Barrett 1999; Bruno and Thomas 2008; Escobar 1999; Ingold 2000; McGlade 1999).

In this article, we first assess political ecology and its application to archaeology in general, and to the emergence of specialized Andean pastoralism in particular. We see this specialized pastoralism as the culmination of underlying social, cultural and economic structures rooted in a deep-time development of Andean pastoralism. We therefore view the political ecology of Andean pastoralism from the perspective of structuration theory (Giddens 1984). We also consider risk and uncertainty theory (Halstead and O'Shea 1989) as applied to Andean pastoralism (Bollig and Göbel 1997; Browman 1987; Escola 1996) and reassess it within the broad parameters of political ecology. Following this, we discuss the process of herding specialization in both case-study areas highlighting the differences and similarities in this coeval process. Based on the conclusions from our case studies we then reemphasize the importance that camelid pastoralism had for Prehispanic cultural development, before - but especially for - the period after A.D. 1,000.

\section{Towards a political ecology of archaeology}

As a theoretical field, political ecology is a relatively recent development, emerging from concerns in the 1970s and 1980s about environmental crises and the cost of human action on the planet (Robbins 2004). Although the term was first coined much earlier and used in the early 1970s, as a field of study it coalesced during the late 1980s and early 1990s, especially with the founding of this journal specifically dedicated to its study and propagation (Greenberg and Park 1994). Grounded in critical thought and political action, it brings together such diverse disciplines as geography, ecology, politics and anthropology under a Marxian umbrella (Leff 2012) integrating the themes of production and social relations inherent in political economy with human and cultural ecology (Paulson, Gezon and Watts 2003). Emerging from the academic fields of geography and anthropology, its application to archaeology has largely been implicit (Beresford-Jones et al. 2009; Erickson 1993; Lane 2006b), rather than explicit (although see Kosiba and Hunter 2017, for a recent application of political ecology and GIS to archaeology, and Lohse 2013 for an edited volume on archaeology and political ecology).

The field's anthropocentric focus on political economy, ecology, and landscape use and change holds obvious appeal for archaeological interpretation (Blaikie 1999; Zimmerer 1994). For South American archaeology, political ecology offers a break with the eco-systemic interpretations that are still so prevalent in the literature (e.g. Kolata et al. 2000) opting rather for a view of past human adaptation and ecology where people are the decisive actors and participants in the use of the environment and the ecological consequences arising from these decisions. 
As a field, political ecology covers a very wide remit, nevertheless, basic tenets cut across all political ecology approaches, summarized by Robbins (2004: 14-15) as understanding degradation and marginalization; environmental conflict; conservation and control; and environmental identity and social movements. All these issues are relevant to archaeological interpretation. Furthermore, political ecology explores the different interlaced levels of power and the exercise of this power in determining human action and impact on the environment and ecology.

Taking an anti-determinist perspective, political ecology engages with the production of landscape by human agents and non-human phenomena, such as climate and the environment. In the case of human agents, political ecologists explore the complex relations of power among different groups and classes of actors and how this sets the agenda of use and access to resources, examining how this then plays out in the formation of landscape. In so doing, political ecology has moved away from linear chains of explanation in favor of networks analyzing the complex and shifting connections that underpin human-human and ultimately human-ecology relationships. Running parallel to this anti-deterministic stance, political ecology juxtaposes ecological disequilibrium and equilibrium; human maladaptation alongside adaptation; and environmental flux, rather than homeostasis as the basic undercurrent of our experience of the world (Paulson, Gezon and Watts 2003: 207). For political ecologists, ecological systems are open, volatile and essentially non-static. Rather than being passive recipients of environmental conditions, humans are seen, alongside natural phenomena, as an important cause of this instability and the main exponent of large-scale landscape change (e.g. Lentz 2000).

In turn, political ecology's emphasis on politics, power and economy (broadly defined) highlights the impact exerted on local ecologies by interests and social relationships located extra-locally. This defies the tendency by human and cultural ecologists to see social problems, such as for instance, overpopulation, poor land management and inadequate technology as the consequence of local decisions (Paulson, Gezon and Watts 2003: 206). Rather, political ecologists opt for a holistic approach that examines the effects of power at different local, regional and extra-regional scales and how this impacts across different groups and class of people and ultimately on the ecology (Paulson and Gezon 2004).

Archaeologically, political ecology forces us to consider the possible non-proximal factors that influenced human use and access to the environment and how these in turn shaped past landscapes, fully cognizant that time is a fundamental factor in determining shifting human political strategies of use, and abuse, of these landscapes. Time also conditions us to reflect on non-human, long-term patterns that impact on local ecology, such as pre-industrial era climatic change. As opposed to the (usually narrow) timeframe considered by political ecologists, archaeologists (and historians) employing political ecology need to be aware of the preexisting, and continually evolving, environmental conditions that prevail within a given area. Archaeological political ecology should then strive to reveal the human relations and power dynamics that exploited these environments, transforming them into human landscapes.

We can define power as the asymmetric access by human groups to resources and risk, and how this then plays out across the relations between these groups. In which case, political ecology charts how these relationships and their power dialectics impact on the environment. In this sense, the 'political' in political ecology constitutes the various politically driven economic practices - the political economy - that mediates land-use through strategies of "domination, accommodation, and resistance" (Zimmerer 1991: 444). Likewise, at the local level human agents negotiate these external and internal politico-economic demands through preexisting, though constantly changing, social structures and practice (Zimmerer 1991).

Structuration theory (Giddens 1984) is succinctly summarized by Shanks and Tilley (1987: 128):

The practice of individuals is both structured and structuring, articulating meaning and conduct in a system of difference, creating meanings for action and conduct and conditions for the interpretation of those meanings and reproducing of transforming structures.

Thus, there is a duality of structure in which structure embedded in rules and resources underlie the construction of social systems. These transcend space and time in the social actions of agents who draw upon these structures through the medium of embedded memory (Gidden's memory traces). This results in the formulation of 'new' 
structures and thus the recursive cycle between structure and agency is established, in which structure is the result of human agency, but at the same time conditions this same agency (Giddens 1984).

Developing this idea, we adopt an ontology-in-situ perspective as set by the meso-level of analysis suggested by Stones (2005) in his strong revision and reformulation of Giddens' original structuration theory. The meso-level involves studies at the community scale and was determined by as being "sufficiently discriminating, austerely delimiting, focus of attention on a restricted number of germane points on the historical and geographical landscape" (Stones 2005: 82). It provides the necessary level within which to engage in archaeological interpretations at a local and regional scale. Furthermore, Stones' adoption of Cohen's (1989: 210) position-practice concept in which different identities or groups within a structure reflect divergent needs, duties and concerns, and therefore act differently gives substance to particularist group agency (Stones 2005: 62). A particularist group agency, in turn, serves as a useful conceptual bridge between structuration theory and political ecology with its interest in the political motivation of classes, groups or actors and how it impinges on the wider ecological sphere. Finally, structuration theory with its recursive diachronic dialectic between structure and agency provides the necessary flux with which to consider the changing political and economic priorities addressed by political ecology.

It is political ecology's underlying structuralism and the pivotal role that it accords to actors that indelibly relates it to structuration. Thus, in applying structuration to political ecology it is possible to subsume a broadly conceived ecology (cyclical or incremental climate change, natural resource availability, etc.) as part of that gamut of external material structures that hedge, but do not necessarily limit group agency. Indeed, the importance of ecology as a non-human conditioning agent has been remarked upon by different scholars, who have nevertheless questioned its primacy in cultural change and adaptation (Butzer 1996; Denevan 2001; Mayer 1985; Lentz 2000; Zimmerer 1999).

Therefore, in inverting the ecology-human relationship towards a more anthropocentric political ecology perspective, Skill (2012: 1) emphasizes how human agency and structure - the duality of structure - determines the what, who and how of human impact on the ecology, what she termed ecological action space. Although Skill construes this ecological action space as environmentally responsible and friendly (2012: 12), we seek to broaden its remit to describe the whole spectrum of human-on-ecology impact. By implication then, human ecological awareness and subsequent action in a given time and place is structured by the internal and external, social, institutional and material structures that underpin that society. Yet within this recursive relationship between agent and structure, ecology is equally a facet, amongst many, of this same structure.

\section{Towards the structuration and political ecology of Andean pastoralism}

If, as Zimmerer (1991: 444) states "[structuration theory] link[s] the social practices of land users to the structural conditions of peasant agriculture..." then to paraphrase, structuration theory must likewise link the social practices of herders to the structural conditions of pastoralism. Thereby, in applying the concept of structuration to the political ecology of Andean pastoralism we are assessing herder social practice (agency) against, and within, the political, ecological, social and cultural conditions (structures) that underscore the diachronic development of pastoralist economies in the two case studies.

In discussing a political ecology of Andean pastoralism, it is first important to recover this activity and the social, cultural and economic structures constructed around it from the marginality to which it has been traditionally consigned (Flores Ochoa 1980, 65). Elsewhere we have stated that Andean pastoralism was a crucial cornerstone of highland economies rather than a marginal pursuit (Lane and Grant 2016); in support of herding's known importance to the Inka state in the Central Andes (Murra 1980), we also have abundant data attesting to its prevalence in Late Intermediate Period (A.D. 1,000-1,480) societies (e.g. Lane 2006b; Parsons, Hastings and Matos Mendieta 1997; Stanish 2001, among others) for the Middle Horizon (A.D. 650-1,000), while Tiwanaku has always been closely associated with pastoralism (Capriles 2011; Kolata 1993, 1996; Lynch 1983), Wari is also being increasingly linked to pastoralism as part of a mixed maize-camelid/farmer-herder economy (Finucane 2009; Finucane, Maita Agurto and Isbell 2006; Meddens 1989). This type of mixed economy sheds important light on the hybrid economic structure of Andean highland societies. 
Indeed, Andean pastoralism has a pedigree that stretches back into the fourth millennium B.C. (Browman 1989), possibly with a number of domestication foci in the Central (Bonavia 1996; Wheeler PiresFerreira, Pires-Ferreira and Kaulicke 1977) and Southern Andes (Grant 2014; Mengoni and Yacobaccio 2006; Yacobaccio et al. 1997-1998). These studies, as well as numerous others (Capriles 2011; Dransart 2002; Kuznar 1990; McGreevy 1989; Webster 1973; Yamamoto 1985), serve to emphasize the deep-time existence and resonance of pastoralism for the construction and structuring of Andean highland society.

This last point is crucial when interpreting Andean highland cultural trajectories. If we accept an underlying pastoralist structuration to Prehispanic Andean highland society then we must account for its present-day marginality. This can be explained by the cumulative disruption, disjuncture and destruction that camelid pastoralism suffered at the hands of sixteenth and seventeenth century Spanish colonization (e.g. Cook 1981; Stern 1993; Van Buren 2010). More so than with native agriculture, camelid pastoralism suffered acutely from debilitating animal plagues (Bonavia 1996; Flannery, Marcus and Reynolds 1989; Flores Ochoa 1980), the introduction and substitution of camelids by Old World animals (Wheeler, Russel and Redden 1995), and the attempted imposition of a Mediterranean style animal economy (Butzer 1988; Gade 1992).

In effect, this precipitated a dramatic decline in camelid pastoralism and the society it underpinned (Flores Ochoa 1980). The same cannot be said of agriculture where New World and Old World cultivars were grown successfully side-by-side. In essence, it was this decline that explains why camelid pastoralism was eventually relegated to the margins of highland society. Its marginality was reinforced by continuing Spanish colonial, and later Republican, policies which emphasized Old World animals and the spread of agriculture to, and beyond, their widely accepted ecological limits, overtaking camelid pastoralism. In reinserting Andean pastoralism to understand Prehispanic highland development we would expect to detect the imprint of a herder political ecology in the social, cultural, economic and cosmological structure of these societies. Indeed, we would expect the use of landscape to reflect these group interests.

Past scholarship has described Andean pastoralism as a form of risk management for highland populations (Bollig and Göbel 1997; Browman 1987; Escola 1996) in which strategies - such as economic diversification, mobility, and technology - are pursued to mitigate fluctuations in pasture and water availability. Obviously, the degree of risk is not a constant, but its presence, and the uncertainty it creates in the social and cultural sphere is. In turn, we would argue that this predilection, and human responses, to risk by Andean pastoralist societies helps to constitute their internal structure against the perceived uncertainty of external factors (sensu Stones 2005). Decisions arrived along the route to long-term pastoralist sustainability, however, are not necessarily organized just at a local level. With the emergence of more complex societies, higher-order political actions also influenced local economies. In this respect, as we shall see in the following case studies, the contrast and variance in local and extra-local political ecology was pivotal in the development of agropastoralism between A.D. 600 and 1,000, culminating in a highly integrated, but economically specialized society of herders and farmers.

\section{Case-study 1: Antofagasta de la Sierra}

The first case-study concentrates on the emergence of specialized agro-pastoralist communities in the Antofagasta de la Sierra region, in Northwestern Argentina. Located at an altitude of over 3,300m in the SouthCentral Andes, this area corresponds to the southern sector of the Argentine Puna. From an environmental point of view, the Puna of Argentina is a high desert biome characterized by an arid, cold climate, intense solar radiation due to the altitude, ample day/night thermal range, poor summer rains and low atmospheric pressure. When compared to the Central Andes, this area is both colder and more arid. Consequently, productivity is markedly lower, and mainly concentrated around the few available stable hydrological systems, including wetlands and main hyrdrological basins. Permanent human settlements coalesce at a select number of prime locations, often separated from other such sites by mountains, saltpans and deserts. These conditions ensure a low population density and aggregation, while encouraging population mobility allied to pastoralism and interregional relationships (Nielsen 2009). 


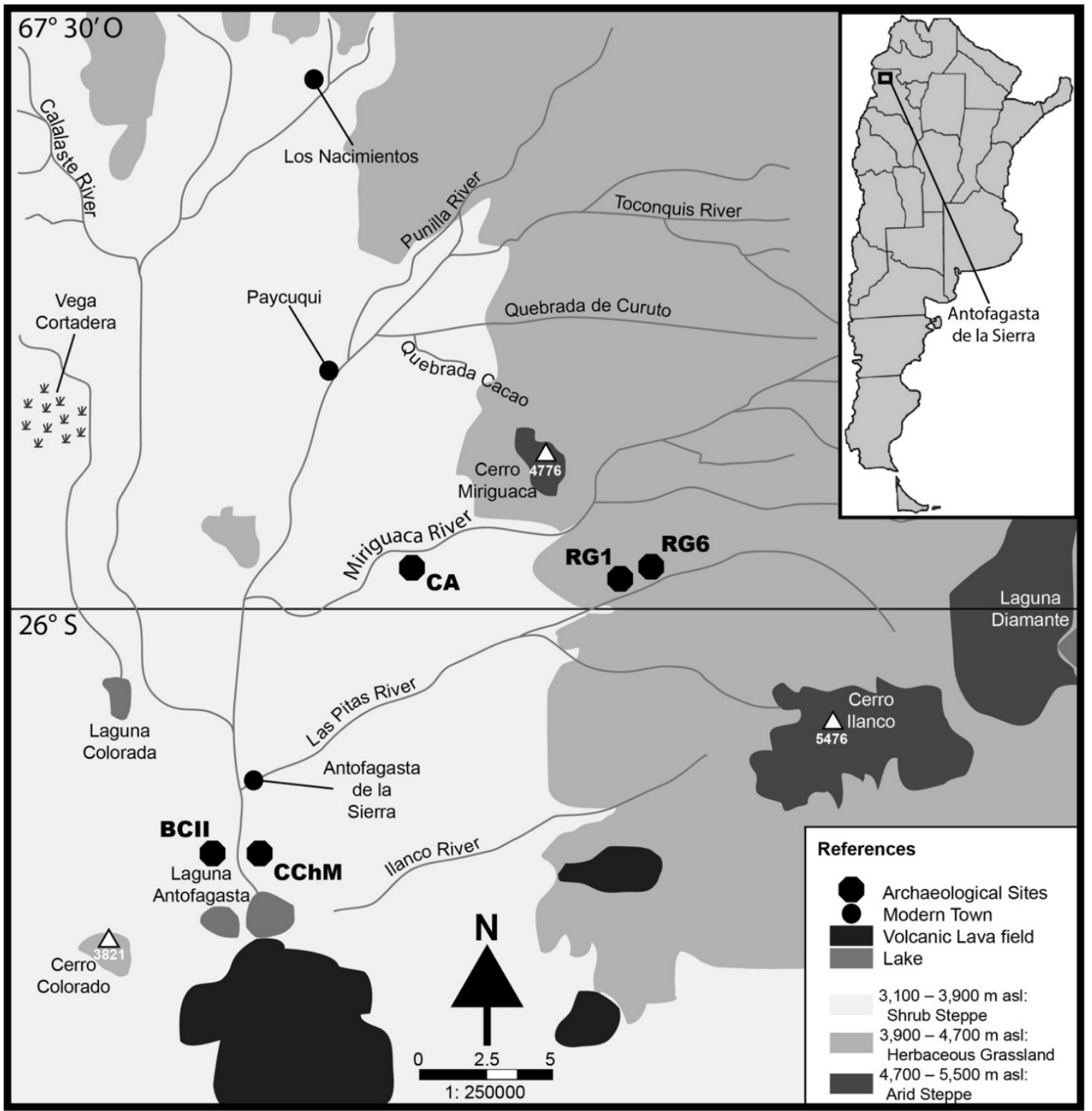

Figure 2: Study area of Case 1. Source: J. Grant.

Antofagasta de la Sierra is part of the salt or Southern puna (drier than the northern puna of Argentina), and it is characterized by its extreme aridity with annual summer rainfall of $\leq 150 \mathrm{~mm}$, including virtually no rain in some years. The environmental setting is defined by a patchy distribution of plant and animal resources with many Nutrient Concentration Zones (Yacobaccio 1994), surrounded by an extreme desert and related to the Río Punilla basin. Therefore, significant variability, fundamentally based on topography and altitude, can be observed over a few kilometers. In the Antofagasta de la Sierra basin, three micro-environmental sectors have been identified, containing concentrated patches of resource rich areas: the Lower Basin (3,400-3,550 m), Intermediate Sectors (3,550-3,800m), and High-Altitude Ravines (3,800-4,600m) (Olivera 2006).

The archaeological evidence for the region reveals the presence of hunter-gatherers from the onset of the Holocene (from at least c. 8,000 BC), focused on the hunting of wild camelids_-vicuña (Vicugna vicugna) and guanaco (Lama guanicoe) (Mondini et al. 2013). Throughout the ensuring millennia, these groups 
underwent numerous social and economic changes, including the selective management of certain camelid populations from an early point in time at c.3,000-2,000 BC (Aschero et al. 2012; Grant 2014, Olivera and Elkin 1994).

From approximately 1,000 BC, there was a consolidation of more sedentary groups vis-à-vis the earlier hunter-gatherers, and towards $200 \mathrm{BC}$ there was the founding of the first village or the first open-air, complex conglomerated structures in the lower basin, alongside the Punilla River. This site demonstrates emergent population sedentism. Llama herding became the principal economic strategy of the area (c. 1,000 BC), with agriculture occupying a secondary role. This agriculture was practiced in alluvial sectors, with water brought onto the fields using short, simple canals (Salminci 2012).

The type of pastoralism adopted at this time was of a generalized character, based on the exploitation of herds composed of medium-sized animals. These animals provided both fiber and meat, and while able to carry loads, where not specialized cargo carriers (Grant 2010; Olivera 1997; Olivera and Grant 2008). The low availability of pasture in the lower basin, coupled with its seasonality would have probably hampered efforts to maintain large herds of domesticated animals. The annual herding cycle conditioned movement to, and from, the lower basin for herders seeking pastures for their domesticated animals, in a transhumance strategy based on range-stock grazing of puna pastures characterized by a predominance of $\mathrm{C}_{3}$ flora, with an emphasis on high altitude (>3,900m) scrublands (Grant 2017). At this time, the family would have constituted the main work and production unit. Each family would have controlled and exploited the resources of specific sectors. In end effect, there was a family or kin-related form of territoriality (Aschero 2000). In turn, kinship networks underpinned by a shared cosmology would have loosely integrated this porous political and ecological landscape (Nielsen 2009).

From AD 200 onwards we detect a slow, human demographic increase among these agropastoralist societies, and a concomitant rise in agricultural production (Olivera and Vigiliani 2000-2002). This process coincides with an increase in the links between agricultural groups in the mesothermal valleys located at a lower altitude, especially those of Hualfin and Abaucan (Catamarca, Argentina). Likewise, links were established with extra-local polities such as La Aguada located further to the South. This period also ushered in a rise in social tension and conflict between the different families over access to the resources located across the different environmental sectors (Martel and Aschero 2007). This conflict has been interpreted as an indicator of incipient socio-political complexity (López Campeny et al. 2005; Martel and Aschero 2007). The emergent rise in complexity would have impacted on the transhumant management strategies employed by the lower basin herders at this time, giving rise to new pastoralist strategies. In this manner, while there is a continuation in the range-stock grazing of the high altitude puna grassland described previously, we detect elements of a new strategy among a number of herders. This new pastoralist strategy was characterized by a contraction in mobility, thereby maintaining the herds nearer to the lower basin settlement, and/or the complementing of their diet through the use of $\mathrm{C}_{4}$ plants as fodder, possibly Prehispanic maize (Grant 2017).

Placing these changes within the wider socio-political context, we find that this economic shift occurs coevally across certain areas of Northwest Argentina, such as the Ambato Valley (Catamarca) and its environs. Here, societies became more complex and there was also political and social intensification linked to the emergence of chiefdoms or señoríos such as La Aguada, during the Middle or Regional Integration Period AD 500-1,000 (Leoni and Acuto 2008). In this setting, similar changes to those seen in Antofagasta de la Sierra have been observed. Shifts in economic strategies in which there was the spatially contiguous practice of plant cultivation and animal rearing (Dantas et al. 2014).

Later, from AD 1,000 AD onwards, and especially after AD 1,250 there is a period of endemic warfare in Northwest Argentina that lasted until the Inka expansion into the area in the fifteenth century. This resulted in a definite shift towards defensive settlement patterns, fortifications, war iconography, new weapons, and osteological evidence for trauma (Nielsen 2009). Even so, this period also sees a flourishing of interregional trade and exchange, seen by the archaeological evidence for caravan routes and campsites. Archaeological sites usually show evidence of non-local items; these items are found in both the mortuary and domestic contexts of permanent villages (Nielsen 2009). 
This volatile period between war, peace and generalized trade is manifested in Antofagasta de la Sierra with the appearance of the fortified, and semi-urban, settlement of La Alumbrera in the lower basin. The site is associated with increased social complexity in the region. The archaeological record and the site architecture suggest that La Alumbrera could have functioned both as a defensive site and as a nexus for trade in goods and caravans to other areas across, and beyond, the Southern puna (Salminci 2012). In this scenario, we have an interregional sociocultural context in which political instability underscored shifting bellicose and peaceful relationships across the region. Trade was most probably conducted with those communities with which one was at peace at a given moment in time (Salminci 2012).

During this period, there seems to have been a marked increase in agricultural production in Antofagasta de la Sierra probably related to the need to produce forage for the ever-increasing numbers of domesticated camelids. There was also a change in settlement location from areas near to the river, in favor of the base of the Cerros del Coypar. By moving to the mid-alluvial terrace, it would have been possible to free up good quality land for use in extensive and intensive agriculture. It was sub-divided into lots delimited by bordos (lineal humps of earth) and fed by water from well planned irrigation canals. Salminci (2012) has calculated that in this manner it was possible to exploit up to 600 ha. In contrast, at present only 80 ha are under cultivation.

Agriculture anchored in the lower basin and involving significant hydraulic investment required a greater degree of sedentism. This move to greater sedentism had repercussions for what type of herding strategies could be adopted. A decrease in transhumance could have led to an increase in the foddering of animals on agricultural residues. This would have made human groups intentionally restrict animals to particular feeding areas - fallow or recently harvested fields - thereby creating a new pastoralist landscape. In this sense, it is possible that substantial agricultural production and irrigation were used to increase available fodder for animals, be it in natural or artificial pastures, rather than just used for human consumption (something similar has been proposed for earlier periods by Olivera (1997) and Olivera and Grant (2008).

In support of the above, nitrogen and carbon stable isotope analysis on human remains from archaeological contexts have highlighted the predominance of meat in these people's diet. While there is evidence that maize (a plant with a $\mathrm{C}_{4}$ photosynthetic signal) was grown in the region, for instance the Quebrada de Petra site was probably a maize storage site (Olivera and Vigliani 2000-2002), maize does not seem to have formed a large part of the human diet (Killian Galvan et al. 2016). This leads us to consider the fact that either this agricultural intensification was geared towards other non- $\mathrm{C}_{4}$ plant species better adapted to high aridity and altitude, or more crucially that $\mathrm{C}_{4}$ plants such as maize were cultivated but largely used as fodder for the llama herds. In turn, some of the llama remains analyzed from this area had a high $\mathrm{C}_{4}$ signal.

With the abandonment of the settlements adjacent to the river, there was also a freeing up of the vegas (naturally irrigated moorland) as an area of additional pasturage. The vegas, together with new irrigation techniques, would have made possible the rearing and management of larger herds. This would seem to be supported by the shift to a more specialized herding of domesticated llamas leading to the appearance of particular camelid morphotypes for, respectively, fiber production and load carrying. The increasing importance of load carrying, and by association trade and exchange, highlights that these exchange and information circuits were crucial to the development of a society that was growing more complex, economically and politically (Olivera and Grant 2008).

Likewise, during this period there was an increase in hunting, mainly of vicuña. This was directly associated with the appearance in the archaeological record of sites dedicated to hunting these animals. In turn, this could suggest a further occupational specialization during the Late Period (Grant 2014; Urquiza and Aschero 2006). This exploitation of vicuña was not just for meat, but also for fiber, leather, etc. which would have been used as trade items with other regions (Grant 2014). Vicuña fiber was particularly prized in Prehispanic Andean society.

This continuation of hunting activities would have reduced the need to kill domestic animals for meat, thereby increasing the prestige and wealth of those who possessed large herds. The richest pastoralists in these societies might have used these herds to, on the one hand, mitigate against environmental risk, but also as social capital towards establishing and maintaining family and kin alliances, as well as opening up access to other resources (Kuznar 1995). We see the emergence in the study area of both specialized herding and hunting 
dedicated to providing different animals products for exchange, within a regional context of increasing caravan traffic (Grant 2014). All these different elements occur in an environmental context underpinned by predominantly arid and unstable conditions. In this sense, data obtained from a variety of palaeoenvironmental records suggest that while between $c$. 2,500 BC - AD 500, the area experienced a very wet and water-rich period, during the last 1,500 years, arid conditions again predominated. From this time onwards, lakes retreated and some of the moor-like vegas degraded, or only survived in the highest sectors of the valleys and ravines (Grana et al. 2016; Tchilinguirian and Olivera 2012).

Against an ecologically deterministic view that would suggest a population decrease during a more arid period, the archaeological evidence points to a strong increase in population in the study area (Olivera et al. 2004). The environment, rather than being a limiting factor, allowed for humans to undertake different actions and alter landscape potential. The development of new herding strategies, together with management of hydraulic technology used to maximize agro-pastoralist production, suggests that pastoralist groups in Antofagasta de la Sierra transformed and created the new economic landscapes they subsequently lived in.

The arrival of the Inkas in the region (c.AD 1,480) leads to the construction of the Coyparcito fort; to Inka structures within La Alumbrera; to the introduction in the region of Inka style ceramics, and new changes to technological infrastructure that led to an even more complex system of agricultural production (Olivera and Vigliani 2000-2002; Tchilinguirian and Olivera 2012). This investment by the Inka state underwrites the importance of the areas for mining, and especially as a point of entry linking strategically vital zones, such as Northern Chile and the mesothermal valleys located to the Northeast, as well as those puna areas located further to the south (Williams and Villegas 2017).

In conclusion, the development of intensive agriculture at the lower basin was related to the development of specialized pastoralism. This involved an increasingly complex management of domesticated herds focusing on maximizing different productive elements (transport, fiber and meat). In turn, this led to a better use of areas apt for pasture, a reduction in mobility linked to the use of agricultural products as fodder, an increase in complex hydraulic technology and the emergence of groups dedicated almost exclusively to pastoralism, as well as farming and hunting.

\section{Case-study 2: North Central Andes, Peru}

The second case-study centers on the emergence of technologically-savvy, agro-pastoralist communities in the North Central Andes, Peru. Located in the Cordillera Negra of the Ancash Province, we concentrate on the area lying above 2,000m in a landscape characterized by steep vertical gradients, small highland plains, and short, narrow ravines fed by fast, seasonally active, high-energy streams. This verdant landscape permitted the development of montane agriculture and high-altitude herding (Brush 1976). Located within the last contiguous area of puna - an alpine-tundra grassland ecozone- this region would have been particularly apt for wild and domesticated camelids.

In the region, the vertical transition between the last agricultural zone (suni), and these puna grasslands, more propitious for herding, is currently set at between 4,000 and 4,100m. Nevertheless, the existence of a strict altitudinal division between farming and herding is disputable (see Mayer 1985; Zimmerer 1999). Indeed, it has been argued that the effective limits of high altitude camelid pastoralism were considerably lower in the past at between 3,300 and 3,600m (Lane and Grant 2016).

Furthermore, given the region's location at the juncture between the puna and the paramo - the cold humid, subtropical grasslands that extend all the way up to Colombia - the area is wetter than other parts of the Andes, with an average rainfall of between 500 and 1,000mm per year. As such the Cordillera Negra is part of the wet puna (Custred 1977), rather than the salt and dry puna of the first case-study.

Even so, as opposed to the adjacent Cordillera Blanca (white mountains), the Cordillera Negra (black mountains) are not topped by a glacier. So although rainfall is high, maintaining runoff is a persistent problem, so that water scarcity was, and is, a constant complaint across this mountain range (Rasmussen 2015). In the Prehispanic past, water scarcity was ameliorated through recourse to geological water storage in silts and by developing dams and reservoirs (Lane 2009, 2017). 


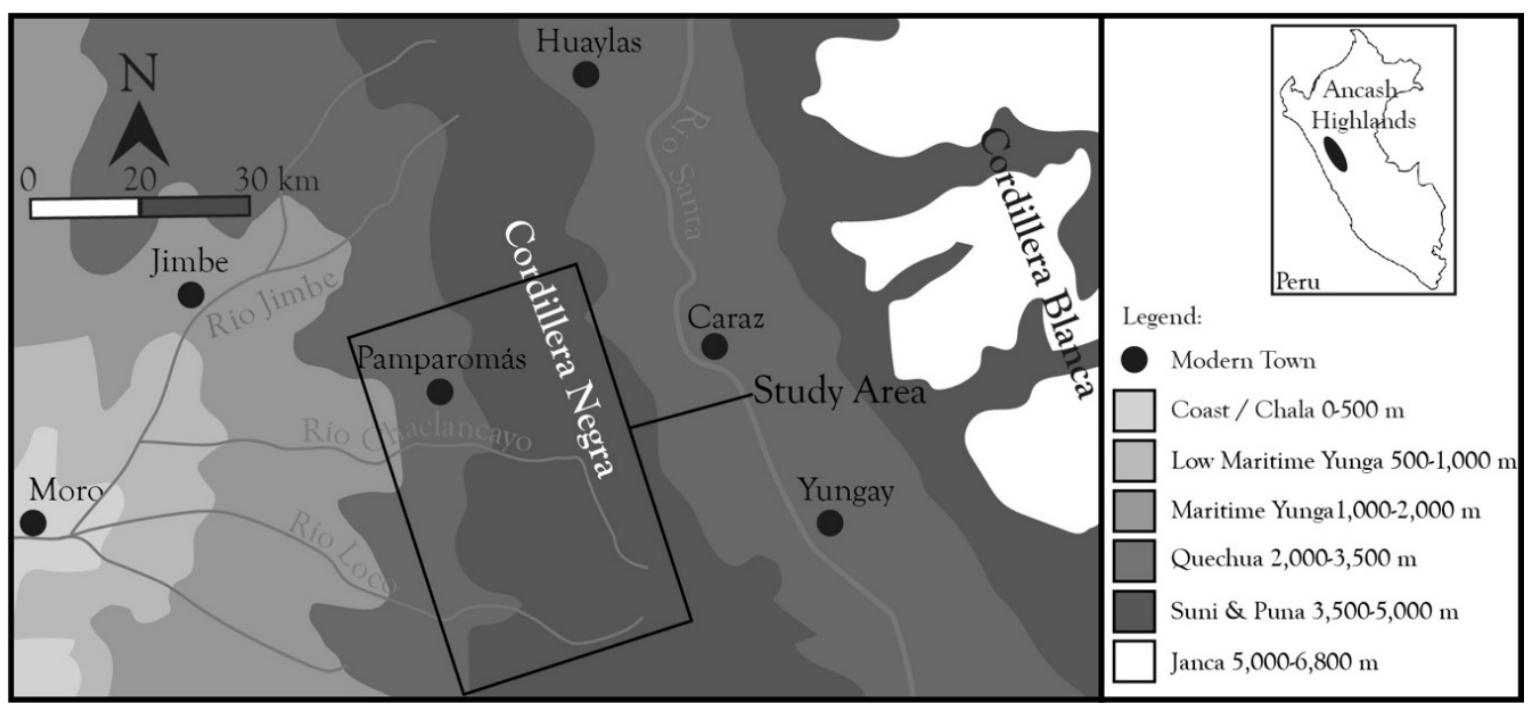

Figure 3: Study area of Case 2 in Peru. Source: K. Lane

Located across the whole of a watershed, these water storage infrastructure works came together with other hydraulic technology, such as terraces, canals and ponds to create water regimes, understood by Orlove and Caton (2010: 406) as, "...the aggregate of institutional rules and practices for managing water resources in a specific setting or watershed." In turn, these various hydraulic systems were created and maintained for hundreds of years. Conservative estimates place the initial building of these to the late Early Intermediate Period (100 BC - AD 600), or early Middle Horizon (AD 600 -1,000), yet they really come into their own during the Late Intermediate Period (AD 1,000-1,480), and subsequently under the Inka Empire (Late Horizon: AD 1,4801,532), before dis-use and abandonment in during the Spanish Colonial Period (Lane 2009, 2013).

We focus on the development of Late Intermediate Period and Late Horizon societies in the Cordillera Negra, as the indigenous Huaylas people negotiated the denouement of the Middle Horizon Wari Empire, and the rise of new, more localized forms of political and economic control, before the region's absorption into the emergent Inka Empire. Essentially, there was an agro-pastoralist landscape in which agriculture and herding were both practiced. Nevertheless, these activities were not mutually exclusive, so that there were farmers with animals, amid pastoralists who engaged in some limited farming. Still, towards and during the Late Intermediate Period there was an ever-increasing specialization.

The study area has a Late Intermediate Period landscape, although ten radiocarbon dates attest to the region being extensively occupied from the end of Middle Horizon through to the early Colonial Period (Lane and Grant 2016: 148). During extensive fieldwork (1999-2008) we identified 59 habitation sites ranging from small farmsteads, to herder estancias and major settlements, as well as 29 hydraulic structures including dams, reservoirs, and canals.

Elsewhere, we have argued that this was a herder landscape (Lane and Grant 2016: 143-151), citing ethnohistoric sources for the period (Duviols 1973; Rostworowski 1988), and the higher incidence of settlements within the optimal herder zone. Also the hydraulic technology employed, especially the silt reservoirs (or check dams) and larger silt dams, suggest a herder-dominated economy and society. In particular, our research showed how during the Late Intermediate Period, there was a downward push by herders to the upper limits of the optimal agricultural zone, effectively bringing pastoralism downslope and thus harnessing a greater area for herding. This same pattern of herder expansion has been identified for this period in other parts of the Andes (Lane and Grant 2016: 153).

Aside from the political fallout of the collapse of the Wari Empire, climatic change is often cited as an important reason behind the social and economic changes that occurred during the Late Intermediate Period 
(Seltzer and Hastorf 1990). A broad brush of the paleo-environmental data for the period suggests warmer conditions during the eleventh through to the early fourteenth century, favoring farming (Baker et al. 2001; Bird et al. 2011; Kellerhals et al. 2010; Mächtle and Eitel 2012; Neukom et al. 2011; Thompson et al. 2013). Followed by wetter, colder conditions during the Fifteenth Century and subsequently, this would have been propitious for herding. Nevertheless, local conditions varied substantially (Chepstow-Lusty et al. 2009).

Under these broad environmental parameters there was some incongruity, given that farming would have been the best strategy to follow during the Late Intermediate Period. Yet, the opposite seems to have happened across the Andes, and in the study area. This did not abate with the coming of the Inkas, with colonists (mitimaes) being trained as herders before being sent to distant provinces (Brotherston 1989). Indeed, conquest of the Southern part of the Inka Empire during this period (Chile, Southern Bolivia and Northwestern Argentina) could well have been linked to the need to use the abundant herds of llama native to this region (D'Altroy, Williams and Lorandi 2007: 116). Therefore, there must be other proximate factors at work to account for the rise of pastoralism during the Late Intermediate Period and Late Horizon in the Central Andes and in Prehispanic Ancash.

Indeed, the case is not so much that farming declined, but that the intensity of pastoralism increased. For the study area the basic Middle Horizon triad of products - maize, potato and camelids (sensu Finucane 2009) - coupled with hydraulic technology that was already in place by AD 1,000, when the Wari Empire and its direct influence over this area entered into decline. Although no bona fide Wari sites have been found, there is significant evidence for Middle Horizon ceramics from funerary contexts, attesting to links between this area and the imperial core. By c.AD 1,000 we already have the emergence of specialized farmers and herders (Lane 2009: 179-180).

While we do not consider climate the prime determinant, the more arid conditions of the $11^{\text {th }}$ to $14^{\text {th }}$ Century would have necessitated the need for greater investment in hydraulic technology. Given the Cordillera Negra's propensity to lose water through runoff, the adopted strategy was recourse to geological storage through dams and reservoirs. As stated above, construction of these structures probably commenced during the Middle Horizon but were given further impetus during the Late Intermediate Period. By this stage, the local Huaylas communities were organized segmentally or acephalously around kin-groups known as ayllus combining farmers and herders. From within these groups, hereditary or elected water priests, judges or managers otherwise known as cilquiua, camayuc, or cochacamayuc would have managed access to, and repair of the extant hydraulic technology (Lane 2009: 183), much in the same way as today (e.g. Gelles 2000; Mitchell and Guillet 1994; Rasmussen 2015). Crucially, for the area, the herder llacuaz were said to predominate over the huari farmers (Duviols 1973).

Given the altitude at which these systems commence, control of the headwaters of these various water regimes would have been held by the specialized herders, this is strongly supported by the ethnohistoric records (Duviols 1973; Rostworowski 1988). In these circumstances, we would see the gradual imposition of a herder orientated economy and social landscape. In our area, this is reflected in the creation and extension of silt dams and reservoirs into upper limits of viable agriculture (Lane and Grant 2016). Equally important was that technology provided the means by which to impose this herder political economy. In this respect, Lemonnier (1993) has emphasized how technology, in this case embedded in the landscape, is an important determinate of the pervading economy.

There is also extensive evidence showing that Late Intermediate Period camelids were being foddered on maize or maize derivatives - stalk, leaves and husk (e.g. Thornton et al. 2011). Furthermore, the number of early colonial sites with churches venerating Santiago - an Andino-Christian syncretic overlap of llibiac the Andean lightening deity venerated by herders - is significant (Hernández Lefranc 2007), further underlining the fact that we are experiencing a herder-dominated landscape. The patron saint of the modern main town in the study area, Pamparomás, is Santiago.

Aside from the local imperatives pushing for an increase in herding production there were external demands as well. The real wealth of the Andes was not gold, but textiles, demand for camelid fiber and cotton was therefore, perforce high (Flores Ochoa et al. 1994; Murra 1980). Late Intermediate Period Huaylas society emerged alongside the consolidation and expansion of important coastal polities, initially that of Casma (AD 
900-1400; Vogel 2012), and eventually the Chimú Empire (AD 900-1470), which encompassed most of the Central and Northern coastal valleys of Peru (Moore and Mackey 2008). Both these polities required camelid fiber for their textiles (Rowe 1984), while an isotopic analysis of the fiber on Central Coast textiles has shown that it came from camelids herded at altitude (Szpak et al. 2015). Evidence for trade can also be found in the highlands. During our site survey, Casma and Chimú ceramics were the only imported wares found for this period, usually used as high-status objects in tombs, although some examples from domestic contexts were also recovered. This would indicate trade between the highlands and coast. It is likely that this trade would have been the preserve of the herders, with their llama caravans. Especially, given the fact that theirs was the main product which was scarce on the coast - fiber, leather and meat - while most of the highland agricultural products could be grown within the areas controlled by these coastal polities.

Towards the end of the Fourteenth Century there is a shift in Late Intermediate Period politics, with evidence for extensive raiding, violence, and a massive increase in fortified hilltop settlements throughout the Andes, from Ecuador to Argentina (Arkush 2008: 4). This pattern is replicated in the study area. Resource exhaustion, both of agricultural soil and through overgrazing has been cited as a possible reason for this downturn (Denevan 1992). In certain areas, shrubs and trees recovered briefly during the Inka Period and following the collapse of the indigenous population in the Sixteenth Century, before declining once more dramatically- in the Seventeenth Century and subsequently (Chepstow-Lusty et al. 2009). We entertain the possibility that under threat from constant raiding, local communities might have been encouraged to concentrate even further on herding, given that in times of crisis, it is easier to move with animals than it is with crops. Many of the hilltop sites in the study area have corrals in close association.

Throughout this period, and into the Inka occupation (AD 1,480-1,532), demand for fiber remained a constant. This is underscored by Inka investment in the area. Very often Inka presence in a given region emphasized political, religious and economic control (D'Altroy 2015). The study area is no different. The two main Inka sites, include the main religious site in the area (Lane 2011), while the other constitutes an Inka administrative settlement astride the main access route, to and from, the valley, built alongside the biggest silt dam in the area (Lane and Contreras Ampuero 2007). There is evidence for Inka reconstruction of at least three of the other existing dams in the area.

Therefore, at a local level the demands probably remain the same, with their old allies the Chimú, now replaced by the Inka state. Politically though, the region falls under more direct control from outside with local production subsumed by the needs of the Empire. This state of affairs continues until the end of Inka rule in the 1530s. The Spanish had a very different agenda, with local camelid herding making way for imported European breeds, which in turn wreaked havoc on the local political economy and ecology (sensu Kennedy and VanValkenburgh 2016).

\section{Discussion}

Time, and especially deep-time, such as that considered here gives us the perspective to appreciate the evolution of a society's political ecology at a local, regional, and even pan-regional scale. By taking the longview we can gauge the accretion and incremental changes to culture and society. In the cases studied here we see the trend towards greater farming and herding specialization already identified for the Andes during the period between AD 600-1,000. This specialization is based around economies of scale, and founded essentially on a triad of highland resources - maize, potato and camelids (Finucane 2009), linked in turn to major economic and hydraulic architectural construction, especially of terraces (Schreiber 1992) and irrigation canals (Korstanje and Quesada 2010). A similar economic model has been proposed for the expansion of the Inka Empire (Chepstow-Lusty et al. 2009).

These economic and structural innovations - driven by the needs of emergent chiefdoms and states (La Aguada - Southern Andes, Tiwanaku - South-central Andes, Wari - Central Andes) - brought with them the wherewithal for specialization on the side of farmers and herders, given that greater productivity required greater time expenditure, while the maintenance of terraces and other economic technology equally required high expenditures of time and effort. In turn, these fundamental economic changes ensured that these two groups would increasingly concentrate on their specific occupations. Nevertheless, the degree of separation of these 
two types of economy should not be over-emphasized. In the Andes, agriculture and herding have always coexisted to varying degrees, with the ensuring economic diversity seen as a means of controlling risk in a harsh environment (Browman 1987).

While the above might suffice to explain the expansion of agropastoralist production for the period between $\mathrm{AD}$ 600-1,000, throughout this article the key question has been, why did pastoralism become so dominant in the Late Intermediate Period (AD 1,000-1,480)? In the highlands, the collapse of larger political and cultural polities such as La Aguada (Northwest Argentina), Tiwanaku (circum-Titicaca Basin) and Wari (Central Andes) heralded a period of smaller independent entities based around corporate kin-groups and a segmented political structure across the highlands (e.g. Lane 2009; Parsons, Hastings and Matos Mendieta 1997). Quite literally we have a balkanization of the whole region (Covey 2008), which is mirrored across large swathes of the Andes (e.g. Acuto 2007, for Northwest Argentina; Arkush 2011, for the circum-Titicaca Basin; Conlee and Schreiber 2006, for the South-central coast).

In this ensuring power vacuum, it is these smaller political groupings that instigate the move towards a further expansion of pastoralism. Although the roots of specialized pastoralism possibly lie in the Middle Horizon (AD 600-1,000), it only comes into its own during the Late Intermediate Period (AD 1,000-1,480). As we mentioned at the beginning, pastoralism -like farming- was a natural human adaptation to this vertical landscape in which fully $30 \%$ of the available land was taken up by puna grassland (Young et al. 2005), and in which economic diversification was a means to managing environmental risk (Browman 1987).

The two case studies presented here address the issue of a rise in specialized pastoralism at different geographical locations, while emphasizing the underlying social structure and political ecology at play. A possible scenario for the period between $\mathrm{AD}$ 1,000 and the coming of the Inka Empire, sees the collapse of these earlier larger chiefdoms and states (La Aguada, Tiwanaku and Wari) precipitating a need for further selfsufficiency on the part of the smaller, successor polities. Under these circumstances it would seem that agriculture became more subsistence-based, given that there was no longer a requirement for a surplus to feed the needs of a state or complex chiefdom. For example, in the case of the circum-Titicaca area, agricultural raised-field systems suffer a 32\% abandonment rate in respect to the earlier Tiwanaku period. Graffam (1992, 896) interprets this $32 \%$ as representing the Tiwanaku state levy on the farmers. The author also makes a persuasive argument for the use of Late Intermediate and Late Horizon Period raised-field production towards the demands for fodder by the region's herders.

This is similar to what we see happening in the Antofagasta de la Sierra case study presented here, in which agricultural intensification in provided both fodder, and released land for increased herding (Olivera y Vigliani 2000-2002; Grant 2014). Similarly, in the Ancash region, a subsistence-based agricultural economy probably encouraged the abandonment, and subsequent use for herding, of the more marginal agricultural areas (Lane and Grant 2016). This asymmetrical relationship would have been further exacerbated by herder control of water sources in the puna. Nevertheless, other proximal reasons for this decrease in agriculture have been suggested, ranging from localized people movement due to increased violence (Arkush 2008), concomitant greater mortality (Arkush and Tung 2013; Kurin 2016), and larger-scale population displacement throughout the Andes (Fehren-Schmitz et al. 2014). That said, the end-effect seems to have been a move towards a more subsistence based existence across the Andean highlands.

Likewise, throughout the Andes, the re-emergence of a greater number of newly independent, smaller polities and concomitantly divergent identities and borders would have increased the need for trade between areas. This underlying diversity, and thereby internal complexity, in Middle Horizon societies has been documented in a recent seminal article by Goldstein (2015) for Tiwanaku. In this context, foreign goods, which would have been previously provided through state or chief exchange mechanisms, now had to be directly bartered for (Stanish and Coben 2013). In these changed circumstances, it would have been the herders with their access to llamas and the trade routes which would have cornered this activity (Nielsen 2009). Indeed, access to foreign goods - obsidian, feathers, spondylus and mullu shell, cotton - was probably an important determining factor in local increases in the numbers of herds and herders.

In this respect, it was the coeval Regional Development (Northwest Argentina) and Late Intermediate (Central Andes) Periods' need for increased self-sufficiency in production, technology and trade, that provided 
the underlying rationale and structure for a changing political ecology that favored pastoralist production over farming. In turn, it is possible that a slowly rising population, soil depletion and overgrazing would have heightened the levels of internecine warfare, leading to an increase in fortified hilltop settlements and defensive redoubts during the $13^{\text {th }}$ Century and subsequently through to the rise of the Inka Empire. Indeed, Late Intermediate Period environmental downturn (Mächtle and Eitel 2012) coupled with a growing population and ecological deterioration would have heightened the incipient social-ecological risk to which these societies were exposed, possibly driving these communities towards risk-management strategies, including the further specialization and exploitation of available resources. In turn, the ability to corral and protect herds in defended sites during moments of warfare would have been a distinct advantage vis-à-vis the stationary agricultural fields.

Against this bleak background, the Inka (originally another one of these late Prehispanic minor polities) exploited the divisions in these communities to bring them into the imperial fold. As with the earlier, Middle Horizon chiefdoms and states, the Inka instigated an increase in agricultural and pastoralist production, now no longer only serving local needs but those of the Empire as well. As a highland phenomenon, the Inka made herding a keystone of their economy (Murra 1965). Yet, the process of over-exploitation and landscape degradation did not stop with the Inka, and there is considerable evidence to suggest that the expansion of herding landscapes precipitated a rise in highland deforestation in certain parts of the Andes (Chepstow-Lusty et al. 1997; Chepstow-Lusty and Winfield 2000; Fjeldså and Kessler 1996), a rise that only accelerated under Spanish colonial society (Gade 1999: 64).

\section{Conclusion}

Taken together, the data presented in these case-studies points to economic change in both areas having been as a consequence of local and extra-local transformations in the political arena across a large swathe of the Andes. These changes where already occurring during the Middle Horizon (AD 600-1,000), but they gathered pace after $\mathrm{AD}$ 1,000, when the larger, more centralized political entities - La Aguada, Tiwanaku, Wari - of the preceding period collapsed. Essentially this involved the decline and disappearance of larger cultural manifestations in favor of largely independent smaller units.

The move to smaller polities did not lead to closed societies, and indeed the need to manage risk and provide adequate sustenance meant that these transformations were characterized by increases in inter-regional trade, lower-order emergent elites, and increasing agricultural and herding specialization. The break-up into smaller polities also generated increasing societal balkanization, which in turn fostered rising internecine warfare and raiding, especially from the Thirteenth Century through to the rise of the Inka (Arkush and Tung 2013). With the Inka, we have the appearance of a new global player (in the context of the Prehispanic Andes), and with it the external demands of a new political ecology. Interestingly -as previously mentionedethnohistoric data suggests that across the Andean highlands the Inka emphasized the continued expansion of herding (Brotherston 1987). This expansion of herding nevertheless accompanied huge landscape innovations, including extensive terrace and hydraulic engineering construction (e.g. Chepstow-Lusty et al. 2009).

In all this, environment and ecology did play its part, given the effects of drought and a colder more arid period after $\mathrm{AD}$ 1,000, but it constituted but another aspect within a wider tapestry of deep social, cultural and economic change by small and later large-scale social groups. Therefore, following Calaway (2005), we caution archaeologists against overly ecological arguments for societal change, opting rather for modifications in the economy and society as a process of gradually shifting demands and expectations as a consequence of the emergence, consolidation, and decline of various local and extra-local polities. In this remit, a political ecology approach to archaeological interpretation serves as an interesting means with which to tackle questions pertaining to that confluence of ecology, environment, human agency and political economy that so interests researchers into the human past.

In conclusion, the particularist group agency approach highlights how political motivations interact with a changing natural environment (Stones 2005). Between c.AD 1,000 and 1500, at the local level, structural changes in the economy and society that had already commenced prior to this period increasing favored specialization of different economic groups, be they farmers or herders (and even perhaps hunters). During the subsequent five centuries, the shifting power dialectic increasingly coalesced around the herders, as the more, 
seemingly adaptable group in a period of increasing political instability, seen in their ability to corner the goods market, and in the changing priorities in agriculture and water technology that favored pastoralists. These changes had a noticeable effect on the landscape, underlining the emergent political ecology of these latter-day agropastoralists, in which changes in the physical landscape provided the imprint of human adaptation to changes in local and regional, social and political conditions. The Inka continued the process of pastoralist consolidation in the Andean highlands, while also further expanding the agricultural frontiers. The Spanish empire heralded the end to this political ecology, bringing with a new global agenda to the concerns of people in the Andes.

\section{References}

Aschero, C.2000. Figuras humanas, camélidos y espacios en la interacción circumpuneña. In M. Podestá and M. de Hoyos (eds.) Arte en las rocas. Arte rupestre, menhires y piedras de colores en la Argentina. Sociedad Argentina de Antropología y Asociación Amigos del INAPL. Pp. 15-44.

Aschero, C., Izeta, A. and S. Hocsman. 2012. New data on South American camelid bone size changes during middle-late Holocene transition: osteometry at Peñas Chicas 1.5 (Antofagasta de la sierra, Argentinian Puna). International Journal of Osteoarchaeology 24: 492-504.

Acuto, F.A. 2007. Fragmentación vs. integración comunal: repensando el período tardío del Noroeste Argentino. Estudios Atacameños: Arqueología y Antropología Surandinas 34: 71-95.

Anschuetz, K.F., R.H. Wilshusen and C.L. Scheick. 2001. An archaeology of landscapes: perspectives and directions. Journal of Archaeological Research 9(2): 157-211.

Arkush, E. 2008. War, causality, and chronology in the Titicaca Basin. Latin American Antiquity 19(4): 339373.

Arkush, E. 2011. Hillforts of the ancient Andes: Colla warfare, society, and landscape. Gainesville: University Press of Florida.

Arkush, E. and T.A. Tung. 2013. Patterns of war in the Andes from the Archaic to the Late Horizon: insights from settlement patterns and cranial trauma. Journal of Archaeological Research 21(4): 307-369.

Baker, P.A., G.O. Seltzer, S.C. Fritz, R.B. Dunbar, M.J. Grove, P.M. Tapia, S.L. Cross, H.D. Rowe and J.P. Broda. 2001. The history of South American tropical precipitation for the past 25,000 years. Science 291 (5504): 640-643.

Barrett, J.C. 1999. Chronologies of landscape. In P.J. Ucko and R. Layton (eds.). Archaeology and anthropology of landscape: shaping your landscape. London: Routledge. Pp. 21-30.

Beresford-Jones, D., S. Arce, O.Q. Whaley and A.J. Chepstow-Lusty. 2009. The role of Prosopis in ecological and landscape change in the Samaca Basin, Lower Ica Valley, South Coast Peru from the Early Horizon to the Late Intermediate Period. Latin American Antiquity 20(2): 303-332.

Bird, B.W., M. Abbott, M.B. Vuille, D.T. Rodbell, N.D. Stansell and M.F. Rosenmeier. 2011. A 2,300-yearlong annually resolved record of the South American summer monsoon from the Peruvian Andes. Proceedings of the National Academy of Sciences 108(21): 8583-8588.

Blaikie, P.M. 1999. A review of political ecology. Zeitschrift für Wirtschaftgeographie 43: 131-147.

Bollig, M. and B. Göbel. 1997. Risk, uncertainty and pastoralism: an introduction. Nomadic Peoples 1: 5-21.

Bonavia, D. 1996. Los camélidos sudamericanos: una introducción a su estudio. Lima: IFEA-UPCH.

Bourdieu, P. 1977. Outline of a theory of practice. Translated by Richard Nick. Cambridge: Cambridge University Press.

Braudel, F. 1980. On history. Chicago: University of Chicago Press.

Brotherston, G. 1989. Andean pastoralism and Inca ideology. In J. Clutton-Brock (ed.) The walking larder: patterns of domestication, pastoralism and predation. London: Unwin-Hyman. Pp. 240-255.

Browman, D.L. 1987. Agro-pastoral risk management in the Central Andes. Research in Economic Anthropology 8: 171-200. 
Browman, D.L. 1989. Origins and development of Andean Pastoralism: an overview of the past 6000 years. In J.Clutton-Block (ed.). The walking larder: patterns of domestication, pastoralism and predation. London: Unwin-Hyman. Pp. 256-268.

Browman, D.L. 2008. Pastoral nomadism in the Central Andes. In H. Barnard and W. Wendrich (eds.). The archaeology of mobility: Old World and New World nomadism. Los Angeles: Cotsen Institute of Archaeology, UCLA. Pp. 160-173.

Bruno, D. and J. Thomas (eds.). 2008. Handbook of landscape archaeology. Walnut Creek, CA: Left Coast Press.

Brush, S.B. 1976. Man's use of an Andean ecosystem. Human Ecology 4(2):147-166.

Butzer, K.W. 1982. Archaeology as human ecology: method and theory for a contextual approach. Cambridge: Cambridge University Press.

Butzer, K.W. 1988. Cattle and sheep from old to New Spain: historical antecedents. Annals of the Association of American Geographers 78(1): 29-56.

Butzer, K.W. 1996. Ecology in the long view: settlement histories, agrosystemic strategies and ecological performance. Journal of Field Archaeology 23(2): 141-150.

Calaway, M.J. 2005. Ice-cores, sediments and civilization collapse: a cautionary tale from Lake Titicaca. Antiquity 79: 778-790.

Capriles, J.M. 2011. The economic organization of early camelid pastoralism in the Andean highlands of Bolivia. Ph.D. dissertation. Department of Anthropology, Washington University in St. Louis.

Chepstow-Lusty A.J., K.D. Bennett, J. Fjeldså, A. Kendall, W. Galiano and A. Tupayachi Herrera. 1997. When two worlds collide: comparing human impact on fragile ecosystems before and after the Inca. Tawantinsuyu 3: 127-134.

Chepstow-Lusty, Alex J., M.R. Frogley, B.S. Bauer, M.J. Leng, K.P. Boessenkool, C. Carcaillet, A.A. Ali and A. Gioda. 2009. Putting the rise of the Inca Empire within a climatic and land management context. Climate of the Past 5: 1-14.

Chepstow-Lusty, A.J. and M. Winfield. 2000. Agroforestry by the Inca: lessons from the past. Ambio 29: 322328.

Cohen, I.J. 1989. Structuration theory: Anthony Giddens and the constitution of social life. Houndmills, UK: MacMillan.

Conlee, C.A. and K.J. Schreiber. 2006. The role of intermediate elites in the Balkanization and reformation of post-Wari society in Nasca, Peru. In C.M. Elson and R.A. Covey (eds.) Intermediate elites in preColumbian states and empires. Tucson: University of Arizona Press. Pp. 94-111.

Cook, N.D. 1981. Demographic collapse: Indian Peru, 1520-1620. Cambridge: Cambridge University Press.

Covey, R.A. 2008. Multiregional perspectives on the archaeology of the Andes during the late Intermediate Period (c. A.D. 1000-1400). Journal of Archaeological Research 16: 287-338.

Custred, G. 1977. Las punas de los Andes centrales. In J.A. Flores Ochoa (ed.). Pastores de puna: uywamichiq punarunakuna. Lima: Instituto de Estudios Peruanos (IEP). Pp. 55-85.

D'Altroy, T. N. 2015. The Incas. 2nd ed. Oxford: Blackwell.

D'Altroy, T., V.I. Williams and A.M. Lorandi. 2007. The Inkas in the southlands. In R.L. Burger, C. Morris and R. Matos Mendieta (eds.). Variations in the expression of Inka power: a symposium at Dumbarton Oaks, 18-19 October 1997. Washington D.C.: Dumbarton Oaks Research Library and Collection.

Dantas, M., G. Figueroa and A. Laguens. 2014. Llamas in the cornfield: Prehispanic agro-pastoral system in the Southern Andes. International Journal of Osteoarchaeology. 24: 149-165.

Dedenbach-Salazar Sáenz, S. 1990. Inka pachaq llamanpa willaynin: uso y crianza de los camelidos en la epoca Incaica. Estudio lingüístico y etnohistórico basado en las fuentes lexicográficas y textuales del primer siglo después de la conquista. Vol. BAS 16. Bonn: Bonner Amerikanistiche Studien.

Denevan, W.M. 1992. The pristine myth: the landscape of the Americas in 1492. Annals of the Association of American Geographers 82(3): 369-385. 
Denevan, W.M. 2001. Cultivated landscapes of native Amazonia and the Andes. Oxford: Oxford University Press.

Dransart, P.Z. 2002. Earth, water, fleece and fabric: an ethnography and archaeology of Andean camelid herding. London: Routledge.

Duviols, P. 1973. Huari y Llacuaz: agricultores y pastores. un dualismo prehispánico de oposición y complementaridad. Revista del Museo Nacional 39: 153-191.

Earle, T. 1997. How chiefs come to power: the political economy in prehistory. Stanford: Stanford University Press.

Erickson, C.L. 1993. The social organisation of pre-Hispanic raised field agriculture in the Lake Titicaca Basin. In V. Scarborough and B. Isaacs (eds.). Economic aspects of water management in the prehispanic New World. Greenwich, Conn.: JAI Press. Pp. 369-426.

Escobar, A. 1999. After nature: steps to an antiessentialist political ecology. Current Anthropology 40(1): 1-30.

Escola, P.S. 1996. Riesgo e incertidumbre en economías agro-pastoriles: consideraciones teóricometodológicas. Arqueología 6: 9-23.

Fehren-Schmitz, L, W. Haak, B. Mächtle, F. Masch, B. Llamas, E. Tomasto Cagigao, V. Sossna, K. Schittek, J. Isla Cuadrado, B. Eitel and M. Reindel. 2014. Climate change underlies global demographic, genetic, and cultural transitions in pre-Columbian southern Peru. Proceedings of the National Academy of Sciences 111(26): 9443-9448.

Fjeldså, J. and M. Kessler. 1996. Conserving the biological diversity of polylepis woodlands of the highland of Peru and Bolivia: a contribution to sustainable natural management in the Andes. Copenhagen: Nordeco.

Finucane, B. 2009. Maize and sociopolitical complexity in the Ayacucho Valley, Peru. Current Anthropology 50(4): 535-545.

Finucane, B., P.M. Agurto and W.H. Isbell. 2006. Human and animal diet at Conchopata, Peru: stable isotope evidence for maize agriculture and animal management practices during the Middle Horizon. Journal of Archaeological Science 33: 1766-1776.

Flannery, K.V., J. Marcus and R.G. Reynolds. 1989. The flocks of the Wamani: a study of llama herders on the puna of Ayacucho, Peru. San Diego: Academic Press.

Flores Ochoa, J.A. 1980. Causas que originaron la actual distribucion de las alpacas y llamas. In L. Milliones and H. Tomeada (eds.). El hombre y su ambiente en los Andes centrales. Osaka: Senri Ethnological Studies. Pp. 63-92.

Flores Ochoa, J.A., K. MacQuarrie, J. Portús, J. Blassi and J. Blassi. 1994. Oro de los Andes: las llamas, alpacas, vicuña y guanacos de sudamérica. Vol. 1. Barcelona: Francis O. Patthey e Hijos.

Franklin, W.L. 1982. Biology, ecology, and relationship to man of the South American camelids. In M.A. and H.H. Genoways Mares (eds.). Mammalian biology in South America. Pittsburgh: University of Pittsburgh Press. Pp. 457-489.

Gade, D.W. 1992. Landscape, system, and identity in the post-conquest Andes. Annals of the Association of American Geographers 82(3): 461-477.

Gade, D.W. 1999. Nature and culture in the Andes. Wisconsin: University of Wisconsin Press.

Gelles, P.H. 2000. Water and power in Highland Peru: the cultural politics of irrigation and development. New Brunswick: Rutgers University Press.

Giddens, A. 1984. The constitution of society: outline of the theory of structuration. Berkeley: University of California Press.

Goldstein, D. 2015. Multiethnicity, pluralism, and migration in the south central Andes: an alternate path to state expansion. Proceedings of the National Academy of Sciences 112(30): 9202-9209.

Graffam, G. 1992. Beyond state collapse: rural history, raised fields, and pastoralism in the South Andes. American Anthropologist 94(4): 882-904. 
Grana, L., P. Tchilinguirian, D. Olivera, C. Laprida and N. Maidana. 2016. Síntesis paleoambiental en Antofagasta de la Sierra: heterogeneidad ambiental y ocupaciones humanas en los últimos 7200 años cal AP. Intersecciones en Antropología 4: 19-32.

Grant, J.L. 2010. Aportes de distintas técnicas osteométricas para la identificación interespecífica de camélidos sudamericanos. In Gutiérrez, M., M. De Nigris, P. Fernández, M. Giardina, A.Gil, A. Izeta, G. Neme and H. Yacobaccio (eds.). Zooarqueología a principios del Siglo XXI. Aportes teóricos, metodológicos y casos de estudio. Buenos Aires: Ediciones del Espinillo. Pp. 17-28.

Grant, J.L. 2014. Manejo económico de camélidos en Antofagasta de la Sierra (Puna Meridional Argentina): una aproximación zooarqueológica e isotópica. PhD dissertation. Facultad de Filosofía y Letras, Universidad de Buenos Aires.

Grant, J.L. 2017. Of hunting and herding: Isotopic evidence in wild and domesticated camelids from the Southern Argentine Puna (2,120 - 420 years BP). Journal of Archaeological Science Reports 11: 29-37.

Greenberg, J.B. and T.K. Park. 1994. Political ecology. Journal of Political Ecology 1(1): 1-12.

Halstead, P. and J. O'Shea (eds.) 1989. Bad year economics: cultural responses to risk and uncertainty. Cambridge: Cambridge University Press.

Hernández Lefranc, H. 2007. De Santiago Matamoros a Santiago-Illapa. Arqueología y Sociedad 17: $313-341$.

Ingold, T. 2000. The temporality of the landscape. In J. Thomas (ed.). Interpretive archaeology: a reader. Leicaster: Leicester University Press. Pp. 510-530.

Kellerhals, T., S. Brütsch, M. Sigl, S. Knüsel, H.W. Gäggeler and M. Schwikowski. 2010. Ammonium concentration in ice cores: a new proxy for regional temperature reconstruction? Journal of Geophysical Research 115: D16123.

Kennedy, S.A. and P. VanValkenburgh. 2016. Zooarchaeology and changing food practices at Carrizales, Peru following the Spanish invasion. International Journal of Historical Archaeology 20(1): 73-104.

Khazanov, A.M. 1984. Nomads and the outside world. 2nd ed. Cambridge: Cambridge University Press.

Kolata, A.L. 1993. The Tiwanaku. Oxford: Blackwell.

Kolata, A.L., ed. 1996. Tiwanaku and its hinterland. Washington: Smithsonian Institution Press.

Kolata, A.L., M.W. Binford, M. Brenner, J.W. Janusek and C.R. Ortloff. 2000. Environmental thresholds and the empirical reality of state collapse: a response to Erickson (1999). Antiquity 74: 424-426.

Korstanje, A. and M.N. Quesada (eds.). 2010. Arqueología de la agricultura: casos de estudio en la región Andina Argentina. Tucuman: Editorial Magna.

Kosiba, S. and R.A. Hunter. 2017. Fields of conflict: a political ecology approach to land and socialtransformation in the colonial Andes (Cuzco, Peru). Journal of Archaeological Science 84: 40-53.

Killian Galvan, V., J. Grant, P. Escola, H. Panarello and D. Olivera. 2016. Análisis de paleodietas humanas en zonas áridas a través de isótopos estables: el caso de Antofagasta de la Sierra (Noroeste Argentino). Revista Colombiana de Antropología 52(2): 199-227.

Kurin, D.S. 2016. The bioarchaeology of societal collapse and regeneration in ancient Peru. Berlin: Springer.

Kuznar, L.A. 1990. Pastoralismo Temprano en la Sierra Alta del Departamento de Moquegua, Perú. Chungara 24/25: 53-68.

Kuznar, L.A. 1995. Awatimarka: the ethnoarchaeology of an Andean herding community. San Diego: Harcourt Brace.

Lane, K. 2006a. Engineering the Puna: the hydraulics of agro-pastoral communities in a north-central Peruvian valley. PhD dissertation, Department of Archaeology. Cambridge: University of Cambridge.

Lane, K. 2006b. Through the looking glass: re-assessing the role of agro-pastoralism in the north-central Andean highlands. World Archaeology 38(3): 493-510.

Lane, K. 2009. Engineered highlands: the social organisation of water in the Ancient North-central Andes (AD 1000-1480). World Archaeology 41(1): 169-190. 
Lane, K. 2011. Hincapié en los Andes nor-centrales: la presencia Inca en la Cordillera Negra, Sierra de Ancash. In K. Lane and M.L. Dávila (eds.) Arquitectura prehispánica tardía: construcción y poder en los Andes centrales. Lima: Fondo Editorial UCSS/CEPAC. Pp. 123-170.

Lane, K. 2013. Entre el agua y la pared: patrimonio, desarrollo, campesinos y arqueólogos en la Cordillera Negra, Perú. In A. Herrera (ed.) Arqueología y desarrollo en América del Sur: de la práctica a la teoría. Bogotá: Ediciones Uniandes. Pp. 97-117.

Lane, K. 2017. Water, silt and dams: Prehispanic geological storage in the Cordillera Negra, North-Central Andes, Peru. Revista de Glaciares y Ecosistemas de Montaña 2(2): 41-50.

Lane, K. and G.C. Ampuero. 2007. An Inka administrative site in the Ancash Highlands, North-central Andes. Past: the Newsletter of the Prehistoric Society 56: 13-15.

Lane, K. and J.L. Grant. 2016. A question of altitude: exploring the limits of highland pastoralism in the prehispanic Andes. In J.M. Capriles and N. Tripcevich (eds.) The archaeology of Andean pastoralism. Albuquerque: University of New Mexico Press. Pp. 139-157.

Leff, E. 2012. Latin American environmental thinking: a heritage of knowledge for sustainability. Environmental Ethics 34(4): 431-450.

Leoni, J.B. and F.A. Acuto. 2008. Social landscapes in pre-Inca northwestern Argentina. In E. Silverman and W.H. Isbell (eds). Handbook of South American archaeology. New York: Springer. Pp. 587-604.

Lemonnier, P. (ed.). 1993. Technological choices: transformation in material cultures since the Neolithic. London and New York: Routledge.

Lentz, D.L. (ed.) 2000. Imperfect balance: landscape transformations in the precolumbian Americas. New York: Columbia University Press.

Lohse, J. C. (ed.) 2013. Classic Maya political ecology: agrarian resource management, political change, and class histories in upper northwestern Belize. Los Angeles: Cotsen Institute for Archaeology, University of California.

López Campeny, S., D. Olivera, V. Fernández Varela and J. Peña. 2005. Procesos tafonómicos, subsistencia y uso del espacio: análisis de la arqueofauna de un sitio agropastoril de la Puna Meridional Argentina (Punta de la Peña 9, Antofagasta de la Sierra,Catamarca). Intersecciones en Antropología 6: 1-28.

Lynch, T.F. 1983. Camelid pastoralism and the emergence of Tiwanaku civilization in the South-Central Andes. World Archaeology 15(1): 1-14.

Mächtle, B. and B. Eitel. 2012. Fragile landscapes, fragile civilizations - how climate determined societies in the pre-Columbian south Peruvian Andes. Catena 103: 62-73.

Martel, A. and C. Aschero. 2007. Pastores en acción: imposición iconográfica vc. autonomíatemática. In A. Nielsen, M.C. Rivolta, V. Seldes, M.M. Vázquez and P. Mercolli (eds.). Producción y circulación prehispánicas de bienes en el Sur Andino. Córdoba: Editorial Brujas. Pp. 329-349.

Mayer, E. 1985. Production zones. In S. Masuda, I. Shimada and C. Morris (eds.). Andean ecology and civilization: an interdisciplinary perspective on Andean ecological complementarity. Tokyo: University of Tokyo Press. Pp. 45-84.

McGlade, J. 1999. Archaeology and the evolution of cultural landscapes: towards an interdisciplinary research agenda. In P.J. Ucko and R. Layton (eds.) Archaeology and anthropology of landscape: shaping your landscape. London: Routledge. Pp. 458-482.

McGreevy, T. 1989. Prehispanic pastoralism in Northern Peru. In J. Clutton-Brock (ed.). The walking larder: patterns of domestication, pastoralism, and predation. London: Unwin-Hyman. Pp. 231-239.

Meddens, F. 1989. Implications of camelid management and textile production for Huari, in Peru. In R. M. Czwarno, Frank Meddens and A. Morgan (eds.). The nature of Wari: a reappraisal of the Middle Horizon period in Peru. Oxford: Archaeopress. Pp. 146-165.

Mengoni, G.L. 2008. Camelids in ancient Andean societies: a review of the zooarchaeological evidence. Quaternary International 185: 59-68. 
Mengoni, G.L. and H.D. Yacobaccio. 2006. The domestication of South American Camelids: a view from the south-central Andes. In M.A. Zeder, D.G. Bradley, E. Emshwiller and B.D. Smith (eds.). Documenting domestication: new genetic and archaeological paradigms. Berkeley: University of California Press. Pp. 228-244.

Mitchell, W.P. and D. Guillet (eds.) 1994. Irrigation at high altitudes: the social organization of water control systems in the Andes. Washington: American Anthropological Association.

Mondini, M., J.G. Martínez, E. Pintar and M.C. Reigadas. 2013. Middle Holocene foraging, mobility and landscape use in the southern Argentinean Puna: hunter-gatherers from Antofagasta de la Sierra, Catamarca, Argentina. Quaternary International 307: 66-73.

Moore, J.D. and C.J. Mackey. 2008. The Chimú empire. In E Silverman and W.H. Isbell (eds.) Handbook of South American archaeology.. New York: Springer. Pp. 783-808.

Moore, K.M. 2016. Early domesticated camelids in the Andes. In J.M. Capriles and N. Tripcevich (eds.) The archaeology of Andean pastoralism. Albuquerque: University of New Mexico Press. Pp. 17-38.

Murra, J.V. 1965. Herds and herders in the Inca state. In A. Leeds and A.P. Vayda (eds.) Man, culture and animals: the role of animals in human ecological adjustments. Washington: American Association for the Advancement of Science. Pp. 185-215.

Murra, J.V. 1980. The economic organization of the Inka state. Connecticut: JAI Press.

Neukom, R., J. Luterbacher, R. Villalba, M. Küttel, D. Frank, P.D. Jones, M. Grosjean, H. Wanner, J.-C. Aravena, D.E. Black, D.A. Christie, R. D'Arrigo, A. Lara, M. Morales, C. Soliz-Gamboa, A. Srur, R. Urrutia and L. von Gunten. 2011. Multiproxy summer and winter surface air temperature field reconstructions for southern South America covering the past centuries. Climatic Dynamics 37 (1-2): 35-51.

Nielsen, A. 2009. Pastoralism and the non-pastoral world in the late pre-Columbian history of the Southern Andes (1000-1535). Nomadic Peoples 13(2): 17-35.

Olivera, D. 1997. La importancia del Recurso Camelidae en la Puna de Atacama entre los 10.000 y 500 años A.P. Estudios Atacameños. 14: 29-41.

Olivera, D. 2006. Recursos bióticos y subsistencia en sociedades agropastoriles de la Puna Meridional Argentina. Comechingonia 9: 19-56.

Olivera, D. and S. Vigliani. 2000/2002. Proceso cultural, uso del espacio y producción agrícola en la Puna Meridional Argentina. Cuadernos del INAPL 19: 459-481.

Olivera, D. and J. Grant. 2008. Economía y ambiente durante el Holoceno Tardío (ca. 4500- 400) de Antofagasta de la Sierra (Puna Meridional Argentina). In Acosta, A., D. Loponte and L. Mucciolo (eds.) Temas de arqueología. Estudios tafonómicos y zooarqueológicos (I). Buenos Aires: Instituto Nacional de Antropología y Pensamiento Latinoamericano. Pp. 99-131.

Olivera, D. and D. Elkin. 1994. De cazadores y pastores: el proceso de domesticación de camélidos en la Puna Meridional Argentina. In Elkin, D.C., C. Madero, G.L. Mengoni Goñalons, D.E. Olivera, M.C. Reigadas and H. Yacobaccio (eds.). Zooarqueología de camélidos. Buenos Aires: Grupo de zooarqueología de camélidos. Pp. 95-124.

Orlove, B. and S.C. Caton. 2010. Water sustainability: anthropological approaches and prospects. Annual Review of Anthropology 39: 401-415.

Parsons, J.R., C.M. Hastings and R. Matos Mendieta. 1997. Rebuilding the state in highland Peru: herdercultivator interaction during the Late Intermediate Period in the Tarama-Chinchaycocha Region. Latin American Antiquity 8: 317-341.

Paulson, S. and L.L. Gezon (eds.). 2004. Political ecology across spaces, scales, and social groups. New Brunswick: Rutgers University Press.

Paulson, S., L.L Gezon and M.J. Watts. 2003. Locating the political in political ecology: an introduction. Human Organization 62(3): 205-217. 
Rasmussen, M.B. 2015. Andean waterways: resource politics in highland Peru. Seattle: University of Washington Press.

Reboratti, C. 2000. Ambiente y sociedad: conceptos y relaciones. Buenos Aires: Ariel.

Robbins, P. 2004. Political ecology: a critical introduction. Oxford: Blackwell.

Rostworowski, M. 1988. Conflicts over coca fields in XVIth-century Peru. Ann Arbor: University of Michigan Press.

Rowe, A.P. 1984. Costumes and featherwork of the lords of Chimor: textiles from Peru's north coast. Washington D.C.: Textile Museum.

Salminci, P. 2012. Espacios residenciales y productivos. El paisaje arqueológico de Antofagasta de la Sierra entre los Siglos XI y XVI D.C. PhD dissertation, Facultad de Filosofía y Letras. Universidad de Buenos Aires.

Sauer, C.O. 1925. The morphology of landscape. University of California Publication in Geography 2(2): 1954.

Schreiber, K.J. 1992. Wari imperialism in Middle Horizon Peru. Anthropological Papers of the Museum of Anthropology Vol. 28. Ann Arbor: University of Michigan Press.

Scoones, I. 1999. New ecology and the social sciences: what prospects for a fruitful engagement? Annual Review of Anthropology 28: 479-507.

Seltzer, G.O. and C.A. Hastorf. 1990. Climatic change and its effect on prehispanic agriculture in the Central Peruvian Andes. Journal of Field Archaeology 17(4): 397-414.

Shanks, M. and C.Y. Tilley. 1987. Social theory in archaeology. Cambridge: Polity.

Skill, K. 2012. The what, who, and how of ecological action space. Sustainability 4: 1-16.

Stanish, C. 2001. Aymara kingdoms. In P.N. Peregrine and M. Ember (eds.) Encyclopedia of prehistory, Volume 7: South America. New York: Kluwer Academic/Plenum Publishers. Pp. 34-37.

Stanish, C. and L. Coben. 2013. Barter markets in the pre-Hispanic Andes. In K. Hirth and J. Pillsbury (eds.) Merchants, markets, and exchange in the pre-Columbian world. Washington DC.: Dumbarton Oaks Research Library and Collection. Pp. 419-434.

Stern, S.J. 1993. Peru's indian peoples and the challenge of Spanish conquest: Huamanga to 1640. Second ed. Madison: University of Wisconsin Press.

Stones, R. 2005. Structuration theory. New York: Palgrave Macmillan.

Szpak, P., F. Longstaffe, F. Surette and G. Lau. 2015. Origins of prehispanic camelid wool textiles from the north and central coasts of Peru traced by carbon and nitrogen isotopic analyses. Current Anthropology 56(3): 449-459.

Tchilinguirian, P. and D.E. Olivera. 2012. Agricultura, ambiente y sustentabilidad agrícola en el desierto: el caso Antofagasta de la Sierra (Puna argentina $26^{\circ} \mathrm{S}$ ). In Korstanje A. and M. Quesada (eds.) Agricultura y desierto. Ediciones Magna, S.M de Tucumán. Pp. 104-129.

Thompson, L.G., E. Mosley-Thompson, M.E. Davis, V.S. Zagorodnov, I.M. Howat, V.N. Mikhalenko and P.N. Lin. 2013. Annually resolved ice core records of tropical climate variability over the past $\sim 1800$ years. Science 340(945): 945-950.

Thornton, E.K., S.D. Defrance, J. Krigbaum and P.R. Williams. 2011. Isotopic evidence for Middle Horizon to $16^{\text {th }}$-century camelid herding in the Osmore Valley, Peru. International Journal of Osteoarchaeology 21(5): 544-567.

Urquiza, S. and C. Aschero. 2006. Avances en el estudio del recurso Camelidae: sitio Punta dela Peña 4, Antofagasta de la Sierra, provincia de Catamarca. In D. Olivera (ed.). Actas del IV congreso mundial sobre camélidos. Santa María (Catamarca), Argentina. Pp. 364-368.

Van Buren, M. 2010. The archaeological study of Spanish colonialism in the Americas. Journal of Archaeological Research 18: 151-201.

Vogel, M. 2012. Frontier life in ancient Peru: the archaeology of Cerro la Cruz. Gainesville: University Press of Florida. 
Webster, S. 1973. Native pastoralism in the South Andes. Ethnology 12: 115-133.

Wheeler, J.C., A.J.F. Russel and H. Redden. 1995. Llamas and Alpacas: pre-conquest breeds and post-conquest hybrids. Journal of Archaeological Science 22: 833-840.

Wheeler Pires-Ferreira, J.C., E. Pires-Ferreira and P. Kaulicke. 1977. Domesticación de los camélidos en los Andes centrales durante el período Precerámico: un modelo. Journal de la Societe des Americanistes 64: 155-165.

Williams, V. and P. Villegas. 2017. Rutas y senderos prehispánicos como paisajes. Las quebradas altas del valle Calchaquí Medio (Salta). Boletín del Museo Chileno de Arte Precolombino 22(1): 71-94.

Yacobaccio, H. 1994. Biomasa animal y consumo en el Pleistoceno-Holoceno surandino. Arqueología 4: 4371.

Yacobaccio, H.D., C.M. Madero, M.P. Malmierca and M. Reigadas. 1997-1998. Caza, domesticacion y pastoreo de camelidos en la Puna Argentina. Relaciones de la Sociedad de Antropologia XXII-XXIII: 389-429.

Yamamoto, N. 1985. The ecological complementarity of agro-pastoralism: some comments. In S. Masuda, I. Shimada and C. Morris (eds.). Andean ecology and civilization: an interdisciplinary perspective on Andean ecological complimentarity. Tokyo: University of Tokyo Press. Pp. 85-100.

Young, K.R., B. Leon, A. Cano and O. Herrera-MacBryde. 2005. Peruvian puna, http://www.nmnh.si.edu/botany/projects/cpd/index.htm. [Web]. Smithsonian Institution.

Zimmerer, K.S. 1991. Wetland production and smallholder persistence: agricultural change in a highland Peruvian region. Annals of the Association of American Geographers 81(3): 443-463.

Zimmerer, K.S. 1994. Human geography and the 'new ecology': the prospect and promise of integration. Annals of the Association of American Geographers 84(1): 108-125.

Zimmerer, K.S. 1999. Overlapping patchworks of mountain agriculture in Peru and Bolivia: toward a regionalglobal landscape model. Human Ecology 27(1): 135-165. 